\title{
Seed rain after a fire in a xerophytic shrubland
}

\section{Lluvia de semillas después de un incendio en un matorral xerófilo}

\author{
Yuriana Martínez-Orea ${ }^{1 凶}$, Silvia Castillo-Argüero ${ }^{1}$, Mariana Hernández-Apolinar ${ }^{1}$, María Patricia Guadarrama- \\ Chávez y Alma Orozco-Segovia ${ }^{3}$ \\ ${ }^{1}$ Departamento de Ecología y Recursos Naturales, Facultad de Ciencias, Universidad Nacional Autónoma de México. Ciudad Universitaria, Circuito \\ exterior $s / n$. 04510, México D. F., México. \\ ${ }^{2}$ Unidad Multidisciplinaria SISAL-Mérida. Facultad de Ciencias, Universidad Nacional Autónoma de México. Unidad Rendón Peniche. Calle 43 s/n x \\ 44 46, Col. Industrial, 97150 Mérida, Yucatán, México. \\ ${ }^{3}$ Laboratorio de Fisiología Ecológica, Instituto de Ecología, Universidad Nacional Autónoma de México. Ciudad Universitaria, 70-275, 04510, \\ México D. F., México. \\ \yurimar29@yahoo.com.mx
}

\begin{abstract}
Fire causes a reduction of plant cover due to the death of several structures, especially of those that are not isolated from high temperatures; such as seeds and fruits. After a disturbance the availability of diaspores is crucial for the recovery of the community. This work studied the composition and abundance of the seed rain in the xerophytic shrubland of the Pedregal de San Ángel Ecological Reserve, located at the Universidad Nacional Autónoma de México campus in Mexico City, which was affected by a surface fire. In order to understand the role of diaspores in the natural regeneration of a burned site, seed traps were placed on 2 sites, one affected by the fire and the other in an unburned location. During 1 year the dispersed seeds and fruits were collected and identified. Results showed that species richness, life forms, and dispersal syndromes were different between sites. The highest abundance and richness values were observed in the burned site. This work offers basic data on the availability of species as diaspores, information which is useful for potential restoration strategies especially in those areas under constant anthropogenic disturbances.
\end{abstract}

Key words: dispersal syndrome, richness, plant diversity, regeneration.

Resumen. El fuego causa la reducción de la cobertura vegetal debido a la muerte de diversas estructuras, especialmente de aquellas que no están aisladas de las altas temperaturas, tal es el caso de semillas y frutos. Dado que estas diásporas permiten la recuperación de la vegetación, resulta crucial entender su composición y abundancia sobre todo después de un disturbio. Este trabajo estudió la composición y abundancia de la lluvia de semillas en el matorral xerófilo Reserva ecológica del Pedregal de San Ángel, localizado en el campus de la Universidad Nacional Autónoma de México en la ciudad de México, el cual fue afectado por un incendio superficial. Con el fin de entender el papel de las diásporas en la regeneración natural se colocaron trampas de semillas en dos sitios, uno quemado y uno no quemado. Durante un año las diásporas fueron colectadas e identificadas. Los resultados mostraron que la riqueza de especies, las formas de vida y los síndromes de dispersión fueron diferentes entre sitios. Los mayores valores de abundancia y de riqueza de diásporas fueron observados en el sitio quemado. Este trabajo ofrece información básica acerca de la disponibilidad de las especies en forma de diásporas, misma que es estratégica en la restauración futura de áreas sujetas a constantes disturbios antropogénicos.

Palabras clave: síndrome de dispersión, riqueza, diversidad, regeneración.

\section{Introduction}

Plant establishment and growth in urban zones are generally affected by the elimination and transformation of natural ecosystems within the areas where humans have become settled (Lundholm and Marlin, 2006). For example, it is well known that temperate forests, aquatic vegetation, and xerophytic shrublands have been fragmented or eliminated in the Endorheic Basin of the

Recibido: 08 abril 2011; 14 octubre 2011
Valley of Mexico, as Mexico City has expanded (Ezcurra, 1992; Ezcurra et al., 2002). Particularly, disappearing xerophytic shrublands are ecosystems that were commonly found between altitudes of $2200-2500 \mathrm{~m}$. This type of vegetation is unique in the world due to its great floristic diversity, being the largest of its type in this area (Rojo, 1994; Carrillo-Trueba, 1995; Challenger, 1998; Lot and Cano-Santana, 2009). Foremost, in the densest city of the world nowadays, this fragmented ecosystem works as an aquifer filter, captures carbon dioxide, provides refuge for many plant and animal species, and harbors endemic taxa (Lot and Cano-Santana, 2009). 
Despite its natural value and ecosystem services, this shrubland has been affected by urban sprawl since the second half of the 20th century, causing a $70 \%$ reduction of its original area (Soberón et al., 1991; Carrillo-Trueba, 1995). In an attempt to mitigate a deeper transformation and avoid the loss of the whole ecosystem, a few protected areas have been established, including the Ecological Reserve of the Pedregal de San Ángel (REPSA). This area, designated in 1983, is located within the campus of the National Autonomous University of Mexico (UNAM; Rivero-Serrano, 1983). As this reserve is surrounded by buildings and wide avenues, it has been constantly affected by garbage deposition, incidence of feral fauna, plant poaching, and fires of different intensity and frequency, generally provoked by humans (Juárez-Orozco and CanoSantana, 2007).

One of the most destructive disturbances was a fire that occurred in 1998. This severe fire was promoted by a prolonged drought and a deep layer of natural fuel load (Martínez-Mateos, 2001). The fire affected $30 \%$ of the reserve and left behind burned patches in several areas. This fire made the mosaic of conserved and perturbed fragments in the REPSA more conspicuous. Some studies on the immediate changes in the physical environment, on the vegetation structure, and on the seed bank dynamics were started in March 1998, immediately after the fire (e.g., Martínez-Mateos, 2001; Martínez-Orea et al., 2010). Accordingly, this study is focused on the sources of the propagule dynamics as the fire caused a drastic reduction in the herbaceous and shrub layers, and left many available open spaces to be colonized (Martínez-Mateos, 2001). In order to know the effect of fire on seed rain, which is one of the main factors that determines community maintenance and regeneration, we assess seed rain composition and richness in burned an unburned sites.

\section{Material and Methods}

Study site. The Ecological Reserve "El Pedregal de San Ángel" hosts a xerophytic shrubland and is located in southwest Mexico City $\left(19^{\circ} 18^{\prime} 31^{\prime \prime}-19^{\circ} 19^{\prime} 17^{\prime \prime} \mathrm{N}\right.$, $\left.99^{\circ} 10^{\prime} 20^{\prime \prime}-99^{\circ} 11^{\prime} 52^{\prime \prime} \mathrm{W}\right)$ at an altitude of $2300 \mathrm{~m}$. It covers a total area of 237.3 ha (171 ha correspond to a nucleus area and 66 ha to a buffer area) (de la Fuente, 2005) (Fig. 1). The climate of the REPSA, including the university campus, in general is temperate sub humid, type $\mathrm{Cb}(w 1)(w)$ (García, 1988), with a mean annual temperature of $15.5^{\circ} \mathrm{C}$ and a mean annual precipitation of $835 \mathrm{~mm}$. There is a marked rainy season from June to October and a dry season from November to May.

Three hundred and seventy 7 species of vascular plants have been reported for this reserve (Castillo-
Argüero et al., 2009). Several authors have suggested that the high diversity found here is closely related to a peculiar environmental heterogeneity generated by a lava flow from the Xitle volcano some 2000 years ago and its posterior cooling off (Martin del Pozzo, 1995; CastilloArgüero et al., 2004) (Fig. 1). Families such as Asteraceae, Poaceae, and Fabaceae have the greatest number of species in the community. Most are perennial, with herbaceous and shrubby species as dominant (Castillo-Argüero et al., 2004, 2007).

As mentioned above, this ecosystem provides services on aquifer recharge, as a carbon sink, in climate regulation, soil formation, nutrient recycling, and plant pollination. Also in conserving biodiversity and gene pools for future generations, since it is a refuge for several plant and animal species.

Seed rain assessment. To assess the nature of the seed rain in the REPSA, we selected 2 100×100 m sites, one affected by the fire in 1998, and another in an unburned area; both sites were contiguous and included all the micro-sites found in the reserve, e.g. longitudinal cracks, domes, flat lava blocks, etc. On each site, 32 conventional seed traps were set at ground level in places generated by using $x$ and $y$ random coordinates. Seed trap measures were 40x40 $\mathrm{cm}$ at the base and $24 \mathrm{~cm}$ in height; they consisted of wire and light cloth, which prevented diaspores from getting moldy. The combined area of all traps was $22.52 \mathrm{~m}^{2}$. Twice a month (from May 1999 to June 2000) we collected the material that fell into seed traps, and examined it under a dissecting microscope. Diaspores were separated, counted, and identified. One of 5 categories of life form (sensu Raunkiær, 1934) and 1 of 10 dispersal syndromes (according to the diaspores morphological structures sensu Dansereau and Lems (1957)) were assigned to each diaspore species. These data and the abundance of diaspores per day and trap were incorporated in a database.

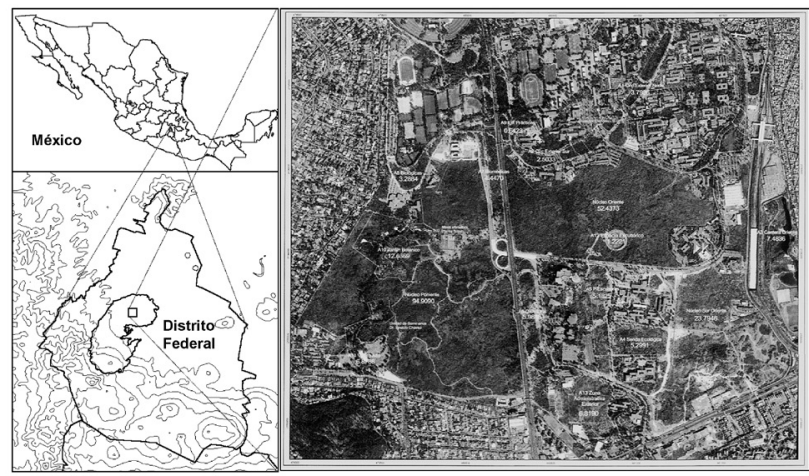

Figure 1. The Pedregal de San Ángel Ecological Reserve (REPSA) in Mexico City (Distrito Federal), Mexico. Orthophotomap modified from de la Fuente (2005). 
Data analysis. We compared the differences in richness and abundance of species between sites and seasons with a Student's $t$-test (StatSoft Inc., 2001); data were previously transformed $[\ln (\mathrm{x}+1)]$. The Shannon-Wiener index was calculated to evaluate species diversity $\left(\mathrm{H}^{\prime}=\right.$ $-\Sigma$ pi $\ln$ pi), where $p i$ is the proportion of individuals of the species $i$ with respect to the total of individuals, calculated as follows: ni/N, where $n i$ is the number of diaspores of the species $i$ and $N$ is the total number of diaspores (Magurran, 1988). A Student's $t$-test was carried out to determine whether there were differences between the diversity values of the burned and the unburned site (Zar, 1974). The Berger-Parker dominance index $(d=N \max / \mathrm{N})$ was calculated, where Nmax is the number of diaspores of the most abundant species and $N$ is the total number of diaspores of all species present in the seed rain. The $\mathrm{S} \varnothing$ rensen similarity index, which for $\mathrm{A}$ and $\mathrm{B}$ sites is given as $[\mathrm{Cs}=2 \mathrm{j} /(\mathrm{a}+\mathrm{b})]$, in which $a=$ number of species in site $\mathrm{A}, b=$ number of species in site $\mathrm{B}, j=$ number of species common to both sites, was also calculated (Magurran, 1988). Differences in abundance of diaspores, categorized by their life forms and dispersal syndromes, were analyzed with chi-square tests per site and season. For each test, adjusted Haberman residuals were calculated to reveal any discrepancies in abundance among categories (Zar, 1974).

\section{Results}

Abundance and richness. A total of 334806 diaspores were captured in the 64 traps during 1 year. This represents a seed density of 1671 diaspores $\mathrm{m}^{-2}$ year ${ }^{-1}$. These diaspores were grouped in 97 identified species, which correspond to 40 families of Angiosperms (Appendix 1). The observed seed rain represents $30 \%$ of the registered species for the REPSA. Five species covered $87 \%$ of the captured seeds: Buddleja cordata (58\%), Muhlenbergia robusta (16\%), Ageratina pichinchense (7\%), Wigandia urens (3.4\%), and Gamochaeta americana (2.5\%). We found 25 species exclusive of the burned site, and 14 of the unburned patch. Similarly, 33 and 11 species were common to both sites during the rainy and dry season, respectively (Appendix 1).

Annual abundance was significantly different between sites and traps $\left(t_{62}=3.25, p=0.002\right)$, more than twice as many seeds were captured in the burned site (233 686) compared to the unburned site $(100,387)$. Even though there are species in fructification all year long, $91 \%$ of the seeds were dispersed during the dry season $\left(t_{62}=12.41, p<\right.$ 0.0001), particularly from October to February (Fig. 2), and $9 \%$ arrived in the traps during the rainy season. The highest availability of seeds occurred in January (Fig. 2). Species richness was significantly different between sites $\left(t_{62}=5.70, p<0.001\right)$, being higher in the burned site (100 species) than in the unburned one ( 89 species).

Diversity, dominance and similarity. The Shannon-Wiener diversity index of the total seed rain was $\left(H^{\prime}=1.67\right)$. In the unburned site the diversity index value $\left(H^{\prime}=1.76\right)$ was slightly higher than the one obtained in the burned site $\left(H^{\prime}=1.45\right)$; however, these values were statistically different $\left(t_{0.05(2) 20930}=1.97<53.27\right)$. The Berger-Parker dominance index for the total seed rain was $\mathrm{D}=0.57$. Dominance values were very similar for the burned site $(D=0.47)$ and for the unburned site $(D=0.45)$. This value also showed variation for the dry season $(D=0.56)$ and for the rainy season $(D=0.46)$. Similarity index values indicated that both sites shared $58 \%$ of the species. This percentage increased when similarity per season was analyzed, during the rainy season $75 \%$ of the species were shared, whereas $65 \%$ were shared in the dry season.

Life cycle and form, dispersal syndromes. Seed rain was composed mostly of perennial species $(63 \%)$, and annuals were present in a smaller proportion (15\%). The remaining species could not be identified. Species were classified according to Raunkiær's system (1934) as 22 phanerophytes, 12 cryptophytes, 10 chamaephytes, 28 hemicryptophytes, and 25 therophytes.

Seed rain abundance categorized by life form was statistically different between sites (burned and unburned; $x^{2}=8420.83$ ), and seasons of the year (rainy and dry; $x^{2}=59$ 846.77). Seasonally, there were differences between sites (rainy, $x^{2}=6$ 909.53; dry, $x^{2}=5$ 256.92). The differences per site were due to the number of diaspores in the burned site. Here with the exception of cryptophytes, the seed rain was 2 to 8 times more abundant in all life forms (Table 1) compared to the unburned site. Phanerophytes were the most abundant during the dry season, showing a 23 -fold increase in diaspores compared to the rainy season (Table 1).

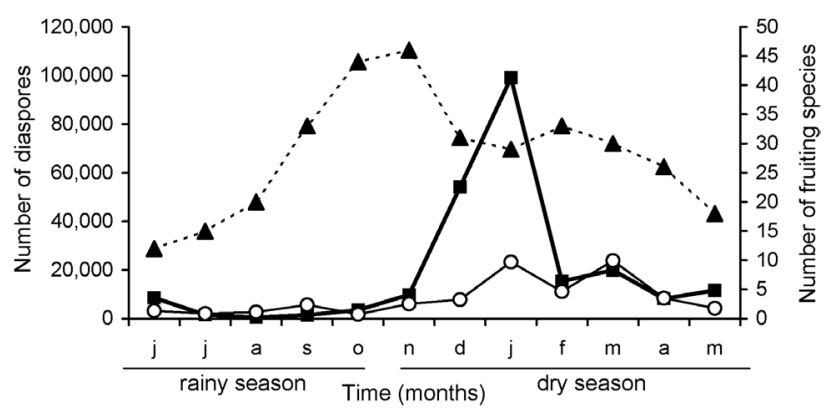

Figure 2. Abundance of diaspores in the seed rain ( $y=$ number of seeds) throughout the year (months) in burned ( $\boldsymbol{a}$ ) and unburned ( $\circ$ ) sites in the Pedregal de San Ángel Ecological Reserve (REPSA). Dotted line shows the number of fruiting species ( $\boldsymbol{\Delta}$ ) in the REPSA (according to Meave et al., 1994). 
Regardless of the site and season of the year, the majority of the seeds that we captured were from Buddleja cordata. Eighty-two percent of the seeds within the phanerophytes belonged to this species (193 649), representing a $58 \%$ of the total seed rain in this shrubland. 95.3\% (54 314) of the diaspores of the chamaephyte life form corresponded to Muhlenbergia robusta, which had a contribution of $16 \%$ of the total dispersed seeds during 1 year. Terophytes contributed $32 \%$ of the total, including 3 species: Drymaria laxiflora (1 239), Conyza canadensis (2 514), and Iresine diffusa (4 746). Conyza canadensis was almost exclusive to the unburned site in the rainy season (2 351), while Iresine diffusa was almost exclusive to the burned site (4 746) during the dry season; Drymaria laxiflora was abundant in the burned site during both seasons of the year and contributed with fewer than 30 individuals in the unburned site (Appendix 1).

Distribution patterns of dispersal syndromes were statistically different between sites and seasons (unburned $x^{2}=37$ 688.05; burned $x^{2}=53$ 636.59). Abundance of diaspores was higher in the burned site in 9 of the 10 syndromes (Table 2). Throughout the year that we monitored seed rain $96 \%$ of the diaspores belonged to 5 syndromes: pogonochory (12 815), acantochory (23 573), sporochory (28 507), sclerochory (59 002), and pterochory (199 628). The highest contribution to the abundance of these syndromes was associated with the following species:
Ageratina pichinchense (acanthochory), Begonia gracilis (sporochory), Buddleja cordata (pterochory), Conyza canadensis (pogonochory), Gamochaeta americana (sporochory), Muhlenbergia robusta (sclerochory), Rhynchelytrum repens (pogonochory), Stevia serrata (pogonochory), Verbesina virgata (pterochory), and Wigandia urens (sporochory) (Appendix 1).

\section{Discussion}

Fire affected severely the seed rain in the xerophytic shrubland of the El Pedregal de San Ángel Ecological Reserve. Our results indicate that fire had significant effects on the abundance, richness, similarity, dominance, and diversity of the seed rain in this ecosystem. In the burned site, vegetation was totally removed thus the "dispersal shadow" was amplified due to the lack of barriers for diaspores to fall on the soil. This space was also opened to those seeds with dispersal syndromes that prevent them from reaching the soil, causing them to remain trapped in the vegetation (Whelan, 1995). The elimination of vegetation by fire allowed the arrival of more propagules, which were mostly $(95 \%)$ characterized by an anemochorous dispersal syndrome (i.e., pogonochory, sclerochory, sporochory, pterochory). Even though $79 \%$ of seed rain in the unburned site was typified also by anemochorous diaspores, the difference in percentage means a 3 times increase of seeds

Table 1. Diaspore numbers in the seed rain according to life forms (sensu Raunkiær, 1934). Phan: Phanerophytes, Cryp: Cryptophytes, Chama: Chamaephytes, Hemi: Hemicriptophytes, Thero: Therophytes. Unbur: Unburned site, Bur: Burned site

\begin{tabular}{lcccccccc}
\hline & \multicolumn{2}{c}{ Site } & \multicolumn{2}{c}{ Season } & \multicolumn{2}{c}{ Rainy } & \multicolumn{2}{c}{ Dry } \\
Life form & Unbur & Bur & Rainy & Dry & Unbur & Bur & Unbur & Bur \\
\hline Phan & 70316 & 165723 & 9775 & 226264 & 2221 & 7554 & 68095 \\
Cryp & 5656 & 2978 & 6022 & 2612 & 4856 & 1166 & 800 & 1812 \\
Chama & 16757 & 40250 & 7254 & 49753 & 4835 & 2419 & 11922 & 37831 \\
Hemi & 2064 & 16484 & 2028 & 16520 & 409 & 1619 & 1655 & 14865 \\
Thero & 2931 & 7772 & 4241 & 6462 & 2603 & 1638 & 328 & 6134 \\
\hline
\end{tabular}

Table 2. Diaspore numbers in the seed rain according to their dispersal syndromes (sensu Dansereau and Lems, 1957). Unbur: Unburned site, Bur: Burned site

\begin{tabular}{lcccccccc}
\hline & \multicolumn{2}{c}{ Site } & \multicolumn{2}{c}{ Season } & \multicolumn{2}{c}{ Rainy } & \multicolumn{2}{c}{ Dry } \\
Dispersal syndrome & Unbur & Bur & Rainy & Dry & Unbur & Bur & Unbur & Bur \\
\hline Acanthochory & 19677 & 3896 & 288 & 23285 & 170 & 118 & 19507 & 3778 \\
Ascochory & 60 & 72 & 44 & 88 & 14 & 30 & 46 & 32 \\
Barochory & 7 & 134 & 7 & 134 & 4 & 3 & 131 \\
Sclerochory & 16609 & 42393 & 9304 & 49698 & 6018 & 3286 & 10591 & 39107 \\
Sporochory & 6515 & 21951 & 10180 & 18286 & 3854 & 6291 & 2516 & 15660 \\
Ixochory & 157 & 759 & 360 & 556 & 108 & 252 & 49 & 507 \\
Pogonochory & 4392 & 8425 & 4370 & 8447 & 2699 & 1671 & 1693 & 6754 \\
Pterochory & 49863 & 149765 & 4019 & 195609 & 1814 & 2205 & 48049 & 147560 \\
Sacochory & 205 & 5412 & 673 & 4944 & 146 & 527 & 59 & 4885 \\
Sarcochory & 198 & 400 & 63 & 535 & 50 & 13 & 148 & 387 \\
\hline
\end{tabular}


in the burned site compared to the unburned patch (Table 2). As natural regeneration in the REPSA depends largely on seed rain (30\% of the species), the observed changes in this process might have important consequences in the composition and structure of this community as in others (Bradstock and O'Connell, 1988).

Even though seed rain richness was high in the REPSA, overall Buddleja cordata was the dominant species in this process. Particularly in the burned site, a 13 to $16 \%$ increase in anemochorous diaspores was associated with this species. This phanerophyte also has been reported to be dominant in the seed bank in the REPSA (MartínezOrea et al., 2010), due to its huge production of tiny seeds easily dispersed by wind, showing successful germination but poor establishment (Mendoza-Hernández et al., 2010). Regardless, this species is favored by disturbances, as it is well represented in the secondary vegetation (Rzedowski and Rzedowski, 2001). Dominance changes through time (Whittaker, 1965), and in this sense, Buddleja cordata apparently is replacing Senecio praecox (Castillo-Argüero, pers. obs.), the dominant species in the recent past (Rzedowski, 1994), through a massive production of seeds, their easy dispersal, and long permanence in the seed bank. In fact this species has recently been observed as abundant in burned sites in the REPSA (Hernández-Herrerías, 2011). Hence, we suggest that seed rain can be the process that explains in part the direction of natural regeneration and future community structure.

The observed changes in the seed rain composition may reflect the natural disturbance regime of the ecosystem, just as in other seasonal communities. Disturbances such as fire would therefore have important consequences in the composition and structure of this community as in others (Bradstock and O'Connell, 1988; Juárez-Orozco, 2005). In the REPSA, this is evident in the case of the herbaceous and annual species, which have been gradually replaced by larger perennial species, such as some shrubs and trees that would have had low frequencies before a disturbance (Martínez-Mateos, 2001).

Similar to Buddleja cordata, Muhlenbergia robusta (chamaephyte) and Wigandia urens (phanerophyte), both with more than 10000 diaspores in the seed rain in this study, showed a high dominance in the burned patch. These species could be also favored by disturbance because of their diaspores dispersed by wind (sclerochorous and sporochorous, respectively).

Additionally, these species are also heliophytes, and their probabilities to colonize the opened areas after a fire are increased. The implications of the increased opportunities for establishment of these species and of Buddleja cordata could be causing a shift in the life forms and/or species dominance in the community. This can have 2 potential ecological consequences: 1 ), the shift in dominance from Senecio praecox to other phanerophytes such as Buddleja cordata and Wigandia urens or 2), the shift in dominance from Senecio praecox to chamaephyes such as Muhlenbergia robusta.

Wigandia urens is also an effective colonizer of deeply disturbed sites, and in the REPSA it might be sharing dominance with Buddleja cordata in areas with exposed rocky substrate. In contrast, Muhlenbergia robusta is dominant in areas with a deeper soil layer (CanoSantana, pers. obs.). Muhlenbergia robusta is a species that survives after a fire due to its clumped growth habit which allows an extensive colonization (i.e., falange type growth sensu Silvertown and Charlesworth, 2007) that avoids germination and establishment of other species, arresting ecological succession (Martínez-Mateos, 2001). Other abundant species in the total seed rain may allow the maintenance of the original vegetation and the regeneration of disturbed sites in the REPSA. This is the case of Ageratina pichinchense, Begonia gracilis, Echeveria gibbiflora, Eysenhardtia polystachya, Senecio praecox, Sedum sp., Senecio sanguisorbae, and Verbesina virgata (Appendix 1).

The absence in the seed rain of $70 \%$ of species reported for the REPSA shrubland is probably due to a number of reasons: 1), 26\% of the species are zoochorous; and a reduced activity of dispersers may be occurring because of restricted movements between fragments or due to the reduction of the habitat (Andrén, 1994; Donovan et al., 1995). A population size reduction of some potential dispersers has been reported for the REPSA by HortelanoMoncada et al. (2009), who in particular report the loss of 6 species of mammals in the area. Nevertheless, mammal and bird populations still show high abundances in conserved patches where food resources are rich (Barja and List, 2006; Chávez-Castañeda and Gurrola-Hidalgo, 2009; HortelanoMoncada et al., 2009), as those where certain species such as Bursera spp., Opuntia spp. and Mammillaria spp. are abundant; 2), barochorous species cover $4 \%$ of all species, and some heavy seeds do not disperse long distances, but fall beneath the parental plant (e.g., Quercus deserticola); and 3), $40 \%$ of those non registered species in the seed rain are dispersed by anemochory. The small size of these diaspores $(\leq 1 \mathrm{~mm})$ reduces their probability of being sampled. This is the case of the Pteridophytes $(10 \%)$ and Orchidaceae, Portulacaceae, and Piperaceae species $(30 \%)$.

Although species richness was significantly higher in the burned site, the similarity with the unburned site was relatively high (58\%). Native species were highly shared between sites (90\%), while only $10 \%$ of the alochthonous species were shared between them. This last group of 
species was registered in the seed rain probably due to their presence in the city where the REPSA is immersed, as occurs in other areas (Zedler et al., 1983; Keith and Bradstock, 1994). In this context, it is important to understand not only the dispersal mechanisms of the species in the seed rain, but the origin of these diaspores as well, to advance predictions on the arrival probability of alien species to the ecosystem. It is particularly important to characterize the presence of introduced species in the seed rain, since this type of plants may cause a decrease in the native species richness of any system (D'Antonio and Vitousek, 1992; Castillo-Argüero et al., 2009). This is the case of Eucalyptus resinifera an introduced species in Mexico that was sampled in the seed rain traps in both sites. According to Segura and Meave (2001), this species may be having noxious effects on the native vegetation of the REPSA.

The open space created by large disturbances such as fire could be a window of opportunity for native weeds or introduced species arriving in the seed rain, and so they represent a risk factor for a potential change in the structure and composition of this system. We found in the seed rain weeds and/or introduced species with relatively high abundances, such as Digitaria ternata, Eruca sativa, Gamochaeta americana, Rhynchelitrum repens, Rumex obtusifolius, Schinus molle, and Sonchus oleraceus that might be favored by fire, and also by the nutrients released by fire.

The feasibility of alternate states resulting from the community dynamics after a major disturbance would depend on stochastic filters related to the nature, timing, and magnitude of the disturbance, distance to the colonization source, and dispersal contingencies, as well as on deterministic filters such as physiological tolerances and interspecific interactions (Lortie et al., 2004). Therefore, we think there is an outstanding need to continuously study and monitor the changes in abundance and richness of the species in the seed rain of this system, in order to understand the dynamics of coexistence and replacement of species over time (Stohlgren et al., 1999). Seed rain is a process of vital importance in the study of regeneration of the REPSA and a sound understanding of it could be used as a tool to establish priorities of conservation and restoration in disturbed sites with a high environmental heterogeneity.

\section{Acknowledgements}

We are grateful to the 2 anonymous reviewers of this article. We also want to thank Silvia Iriarte-Vivar and Irene Pisanty-Baruch for language edition. Oswaldo Núñez helped in the seed traps setting in the field. Juan Manuel
Camacho-Altamirano and Irene Sánchez-Gallén helped in the separation of diaspores. Thanks to Marco A. Romero for his useful help in the elaboration of the map. Very special thanks to J. Alejandro Zavala-Hurtado and Gerardo Rivas for their thoughtful comments.

\section{Literature cited}

Andrén, H. 1994. Effects of habitat fragmentation on birds and mammals in landscapes with different proportions of suitable habitat: A review. Oikos 71:355-366.

Barja, I. and R. List. 2006. Faecal marking behaviour in ringtails (Bassariscus astutus) during the non-breeding period: spatial characteristics of latrines and single faeces. Chemoecology 16:219-222.

Bradstock, R. A. and M. A. O'Connell. 1988. Demography of woody plants in relation to fire: Banksia ericifolia L.f. and Petrophile pulchella (Shrad.) R. Br. Australian Journal of Ecology 13:508-18.

Carrillo-Trueba, C. 1995. El Pedregal de San Ángel. Universidad Nacional Autónoma de México. México, D.F. 177 p.

Castillo-Argüero, S., G. Montes, M. Romero, Y. Martínez, P. Guadarrama, I. Sánchez and O. Núñez. 2004. Dinámica y conservación de la flora del matorral xerófilo de la Reserva Ecológica del Pedregal de San Ángel (D.F. México). Boletín de la Sociedad Botánica de México 74:51-75.

Castillo-Argüero, S., Y. Martínez, M. Romero, P. Guadarrama, O. Núñez, I. Sánchez and J. Meave. 2007. La Reserva Ecológica del Pedregal de San Ángel: Aspectos florísticos y ecológicos. Coordinación de la Investigación Científica. Universidad Nacional Autónoma de México, México, D. F. $293 \mathrm{p}$.

Castillo-Argüero, S., Y. Martínez, J. Meave, M. Hernández, O. Núñez, G. Santibáñez and P. Guadarrama. 2009. Flora de la Reserva del Pedregal de San Ángel: Susceptibilidad de la comunidad a la invasión de malezas nativas y exóticas. In Biodiversidad del Pedregal de San Ángel, A. Lot y Z. Cano-Santana (eds.). Universidad Nacional Autónoma de México, México, D.F. p. 107-133.

Challenger, A. 1998. Utilización y conservación de los ecosistemas terrestres de México: pasado, presente y futuro. CONABIO, México, D. F. 847 p.

Chávez-Castañeda, N. and M. A. Gurrola-Hidalgo. 2009. Avifauna. In Biodiversidad del Pedregal de San Ángel, A. Lot y Z. Cano-Santana (eds.). Universidad Nacional Autónoma de México, México, D. F. p. 261-275.

D'Antonio, C. and P. Vitousek. 1992. Biological invasions by exotic grasses, the grass/fire cycle, and global change. Annual Review of Ecology and Systematics 23:63-87.

de la Fuente, J. R. 2005. Acuerdo por el que se rezonifica, delimita e incrementa la zona de la Reserva Ecológica del Pedregal de San Ángel de Ciudad Universitaria. Gaceta 
UNAM 3813:19-21.

Dansereau, P. and K. Lems. 1957. The grading of dispersal types in plant communities and their ecological significance. Contibutions de L'Institute Botanique de L'Université de Montreal 71:5-52

Donovan, T. M., R. Lamberson, A. Kimber, F. Thompson and J. Faaborg. 1995. Modeling the effects of habitat fragmentation on source and sink demography of neotropical migrant birds. Conservation Biology 9:1396-1407.

Ezcurra, E. 1992. La ecología en los tiempos del cólera. Epílogo. Ciencias 28:73-78.

Ezcurra, E., M. Mazari-Hiriart, I. Pisanty and A. GuillermoAguilar. 2002. Socioeconomic change and its impact on forest resources in the basin of Mexico. In Ecological Studies 156. Urban air pollution and forests. Resources at risk in the Mexico City air basin, M. E. Fenn, L. I. de Bauer, and T. Hernández-Tejeda (eds.). Springer. New York. p. 2443.

Fenn, M. E., L. I. de Bauer and T. Hernández-Tejeda. 2002. Summary of air pollution impacts on forests in the Mexico City air basin. In Urban air pollution and forests. Resources at risk in the Mexico City air basin, M. Fenn, L. de Bauer and T. Hernández-Tejeda (eds.). Springer. New York. p. 337-387.

García, E. 1988. Modificaciones al sistema de clasificación climática de Köppen. UNAM Instituto de Geografía, México, D. F. 217 p.

Hernández-Herrerías, L. B. 2011. Estructura de la comunidad vegetal y de dos poblaciones animales en zonas conservadas y perturbadas de la Reserva Ecológica del Pedregal de San Ángel. BSc. Thesis, Facultad de Ciencias, Universidad Nacional Autónoma de México. México, D. F. 52 p.

Hortelano-Moncada, Y., F. Cervantes and A. Trejo-Ortíz. 2009. Mamíferos silvestres. In Biodiversidad del Pedregal de San Ángel, Universidad Nacional Autónoma de México. A. Lot y Z. Cano-Santana (eds.). Coordinación de la Investigación Científica, Universidad Nacional Autónoma de México. México, D. F. p. 277-293.

Hortelano-Moncada, Y., F. Cervantes and A. Trejo-Ortiz. 2009. Mamíferos silvestres de la Reserva Ecológica del Pedregal de San Ángel en Ciudad Universitaria, Universidad Nacional Autónoma de México, México, D. F. Revista Mexicana de Biodiversidad 80:507-520.

Juárez-Orozco, S. M. 2005. Efectos del fuego y la herbivoría sobre la biomasa aérea del estrato herbáceo de la Reserva del Pedregal de San Ángel. BSc. Thesis, Facultad de Ciencias, Universidad Nacional Autónoma de México, México, D. F. 90 p.

Juárez-Orozco, S. and Z. Cano-Santana. 2007. El cuarto elemento y los seres vivos. Ecología del fuego. Ciencias 85:4-12.

Keith, D. and R. Bradstock. 1994. Fire and competition in Australian heath: a conceptual model and field investigations. Journal Vegetation Science 5:347-354.

Lortie, C., R. Brooker, P. Choler, Z. Kikvidze, R. Michalet, F. Pugnaire and R. Callaway. 2004. Rethinking plant community theory. Oikos 107:433-438.

Lot, A. and Z. Cano-Santana. 2009. Biodiversidad del ecosistema del Pedregal de San Ángel. In Biodiversidad del Pedregal de San Ángel, Universidad Nacional Autónoma de México. A. Lot and Z. Cano-Santana (eds.). Coordinación de la Investigación Científica, Universidad Nacional Autónoma de México, México, D. F. 538 p.

Lundholm, J. and A. Marlin. 2006. Habitat origins and microhabitat preferences of urban plant species. Urban Ecosystems 9:139-159.

Magurran, A. 1988. Ecological Diversity and its Measurement. Princeton University Press, New Jersey. 185 p.

Martin del Pozzo, A. 1995. La edad del Xitle. In El Pedregal de San Ángel, T. C. Carrillo (ed.). Universidad Nacional Autónoma de México, México, D. F. p. 48.

Martínez-Mateos, E. 2001. Regeneración natural después de un disturbio por fuego en dos microambientes contrastantes de la Reserva Ecológica el Pedregal de San Ángel. BSc. Thesis, Facultad de Ciencias, Universidad Nacional Autónoma de México, México, D. F. 66 p.

Martínez-Orea, Y., S. Castillo-Argüero, P. Guadarrama-Chávez and I. Sánchez-Gallén. 2010. Post-fire seed bank in a xerophytic shrubland. Boletín de la Sociedad Botánica de México 86:11-21.

Meave, J., J. Carabias., V. Arriaga and A. Valiente-Banuet. 1994. Observaciones fenológicas en el Pedregal de San Ángel. In Reserva Ecológica el Pedregal de San Ángel: Ecología, Historia Natural y Manejo, A. Rojo (comp.). Universidad Nacional Autónoma de México, México, D. F. p. 91-106.

Mendoza-Hernández, P. E., A. Orozco-Segovia and I. Pisanty. 2010. Germination, emergence, and survival of Buddleia cordata in an urban forest. Ecological Restoration 28:263265.

Raunkiær, C. 1934. The life forms of plants and statistical plant geography. Oxford University Press, Oxford. 632 p.

Rivero-Serrano, O. 1983. Decreto para la creación de una zona ecológica inafectable. Gaceta UNAM. 59.

Rojo, C. A. 1994. Reserva Ecológica "El Pedregal de San Ángel": Ecología, historia natural y manejo. Universidad Nacional Autónoma de México, México, D. F. 410 p.

Rzedowski, J. 1994. Vegetación del Pedregal de San Ángel. In Reserva Ecológica del Pedregal de San Ángel: Ecología, Historia Natural y Manejo. A. Rojo (comp.). Universidad Nacional Autónoma de México, México, D. F. p. 9-64.

Rzedowski, J. and G. Rzedowski. 2001. Flora Fanerogámica del Valle de México. Comisión Nacional para el Conocimiento y Uso de la Biodiversidad. Instituto de Ecología, A.C., Pátzcuaro Michoacán, México. 1406 p. 
Segura, B. and J. Meave. 2001. Effect of the removal of the exotic Eucalyptus resinifera on the floristic composition of a protected xerophytic shrubland in southern Mexico City. In Plant invasions: species ecology and ecosystem management, G. Brundu, J. Brock, I. Camarda, L. Chid and M. Wade (eds.). Backhuys Publishers, Leiden. p. 319-330.

Silvertown, J. and D. Charlesworth. 2001. Introduction to plant population biology. $4^{\text {th }}$ edn. Oxford, UK. Blackwell Science. 360 p.

Soberón, J., M. de la Cruz-Rosas and G. Jiménez. 1991. Ecología hipotética de la Reserva del Pedregal de San Ángel. Ciencia y Desarrollo 99:25-38.

Stohlgren, J., D. Binkley, G. Chong, M. Kalkhan, L. Schell,
K. Bull, Y. Otsuki, G. Newman, M. Bashkin and Y. Son. 1999. Exotic plant species invade hot spots of native plant diversity. Ecological Monographs 69:25-46.

Whelan, R. 1995. The ecology of fire. Cambridge University Press, Cambridge. 346 p.

Whittaker, R. H. 1965. Dominance and diversity in land plant communities. Science 147:250-260.

Zar, J. H. 1974. Biostatistical analysis and its measurement. Princeton University Press, New Jersey. 718 p.

Zedler, P., C. Gautier and G. McMaster. 1983. Vegetation change in response to extreme events: The effect of a short interval between fires in California chaparral and coastal scrub. Ecology 64:809-818.

Appendix 1. List of species in the seed rain (S.R.) registered during 1999-2000. Characteristics such as dispersal syndrome (sensu Danserau and Lems, 1957) and life form (sensu Raunkiær, 1934) are included: $\mathrm{He}=$ hemicriptophyte, $\mathrm{Cr}=$ criptophyte, $\mathrm{Fa}=\mathrm{phanerophyte}$, $\mathrm{Te}=$ terophyte, $\mathrm{Ca}=$ chamaephyte. $\mathrm{E}=$ exotic, $\mathrm{N}=$ native and $\mathrm{W}=$ weed, for type of species column (according to http://conabio.gob.mx/ malezasde mexico/fichas/ficha.htm). The abundance category was set arbitrarily as follows: 1=1-500 diaspores in S.R., 2=501-1 000 diaspores in S.R., 3=1 001-5 000 diaspores in S.R., 4= 5 001-10 000 diaspores in S.R., 5=10 001-50 000 diaspores in S.R., $\mathbf{6}=$ more than 50000 diaspores in S.R. Only identified species are included

Class/Family/Species

Magnoliopsida

Amaranthaceae

Iresine cassiniiformis Schauer

Iresine diffusa Humb. Et Bonpl. Ex Willd

\section{Anacardiaceae}

Schinus molle L.

Apiaceae

Arracacia tolucensis (Kunth) Hemsl.

\section{Asclepiadaceae}

Gonolobus uniflorus Kunth

Metastelma angustifolium Torr.

\section{Asteraceae}

Ageratina mairetiana (DC.) R.M. King \& H. Rob. Ageratina pichinchense (H.B.K.) King \& Rob. Ageratina schaffneri (Sch. Bip.) King \& Rob.

Baccharis sordescens DC.

Barkleyanthus salicifolius (Ruiz \& Pav.) Pers.

Bidens aurea (Aiton) Sherff

Bidens odorata Cav.

Brickellia veronicifolia (Kunth) A. Gray

Conyza canadensis (L.) Cronquist

Dahlia coccinea Cav.

Dahlia pinnata Cav.

Gamochaeta americana (Mill.) Cabrera

Heterosperma pinnatum Cav.

$\begin{array}{cccccc}\text { Dispersal } & \text { Life } & \text { Type of } & \text { Relation in } & \text { Relation } & \text { Abundance } \\ \text { syndrome } & \text { form } & \text { species } & \begin{array}{c}\text { unburned } \\ \text { site }\end{array} & \begin{array}{c}\text { in burned } \\ \text { site }\end{array} & \text { category }\end{array}$

$\begin{array}{cccccr}\text { sacochory } & \text { Fa } & \text { N } & 1 & 5.4 & 1 \\ \text { sacochory } & \text { Te } & \text { W } & 1 & 1185.5 & 3 \\ \text { sarcochory } & \text { Fa } & \text { EW } & 2.2 & 1 & 1 \\ \text { sclerochory } & \text { Cr } & \text { W } & 1 & 5 & 1 \\ \text { pogonochory } & \mathrm{He} & \mathrm{N} & 1.06 & 1 & 1 \\ \text { pogonochory } & \mathrm{Ca} & \mathrm{N} & 2.5 & 1 & 1\end{array}$

$\begin{array}{ccc}\text { ixochory } & \mathrm{Fa} & \mathrm{N} \\ \text { acanthochory } & \mathrm{Fa} & \mathrm{W} \\ \text { pogonochory } & \mathrm{Fa} & \mathrm{N} \\ \text { pogonochory } & \mathrm{Ca} & \mathrm{N} \\ \text { pogonochory } & \mathrm{Fa} & \mathrm{N} \\ \text { acanthochory } & \mathrm{Te} & \mathrm{W} \\ \text { acanthochory } & \mathrm{Te} & \mathrm{W} \\ \text { pogonochory } & \mathrm{Ca} & \mathrm{N} \\ \text { pogonochory } & \mathrm{Te} & \mathrm{W} \\ \text { sclerochory } & \mathrm{Cr} & \text { W } \\ \text { sclerochory } & \mathrm{Cr} & \text { W } \\ \text { sporochory } & \mathrm{He} & \text { W } \\ \text { sclerochory } & \mathrm{Te} & \text { W }\end{array}$

$\begin{array}{ccc}1 & 4.83 & 2 \\ 5.90 & 1 & 5 \\ 1 & 45 & 1 \\ 1 & 2.73 & 1 \\ 1 & 2 & 1 \\ 0 & 2 & 1 \\ 1 & 1 & 1 \\ 1 & 3.23 & 1 \\ 227.55 & 1 & 3 \\ 1 & 1.74 & 3 \\ 1 & 1.8 & 1 \\ 1 & 45.19 & 4 \\ 0 & 2 & 1\end{array}$


Appendix 1. Continues.

Class/Family/Species

Piqueria trinervia Cav.

Senecio praecox (Cav.) DC.

Senecio sanguisorbae DC.

Sonchus oleraceus L.

Stevia ovata Willd.

Stevia serrata Cav.

Tagetes lunulata Ortega

Tagetes micrantha Cav.

Tithonia tubaeformis (Jacq.) Cass.

Verbesina virgata Cav.

\section{Begonicaceae}

Begonia gracilis Kunth

\section{Brassicaceae}

Eruca sativa Mill.

Lepidium virginicum $\mathrm{L}$.

\section{Buddleiaceae}

Buddleja cordata Kunth

Burseraceae

Bursera cuneata Engl.

\section{Cactaceae}

Opuntia robusta Wendl.

\section{Caryophyllaceae}

Drymaria laxiflora Benth.

\section{Casuarinaceae}

Casuarina equisetifolia

\section{Convolvulaceae}

Convolvulus arvensis $\mathrm{L}$.

\section{Crassulaceae}

Echeveria gibbiflora DC.

Sedum $s p$.

\section{Dioscoreaceae}

Dioscorea galeottiana Martens

\section{Euphorbiaceae}

Acalypha indica $\mathrm{L}$.

Euphorbia anychioides (Boiss.) Millsp

Euphorbia graminea Jacq.

Euphorbia hirta L.

\section{Fabaceae}

Brogniartia intermedia Moric.

Dalea zimapanica S. Schauer

Eysenhardtia polystachya (Ortega) Sarg.

Phaseolus leptostachyus Benth

Phaseolus pauciflorus Sessé et Moc.

\begin{tabular}{|c|c|c|c|c|c|}
\hline $\begin{array}{l}\text { Dispersal } \\
\text { syndrome }\end{array}$ & $\begin{array}{l}\text { Life } \\
\text { form }\end{array}$ & $\begin{array}{l}\text { Type of } \\
\text { species }\end{array}$ & $\begin{array}{c}\text { Relation in } \\
\text { unburned } \\
\text { site }\end{array}$ & $\begin{array}{c}\text { Relation } \\
\text { in burned } \\
\text { site }\end{array}$ & $\begin{array}{c}\text { Abundance } \\
\text { category }\end{array}$ \\
\hline sclerochory & $\mathrm{He}$ & $\mathrm{N}$ & 0 & 192 & 1 \\
\hline pogonochory & $\mathrm{Fa}$ & $\mathrm{N}$ & 1.11 & 1 & 1 \\
\hline pogonochory & $\mathrm{He}$ & $\mathrm{N}$ & 1.27 & 1 & 3 \\
\hline pogonochory & $\mathrm{Te}$ & EW & 1 & 13 & 1 \\
\hline pogonochory & $\mathrm{He}$ & $\mathrm{N}$ & 1 & 109 & 1 \\
\hline pogonochory & $\mathrm{He}$ & W & 1 & 13.12 & 3 \\
\hline acanthochory & $\mathrm{Te}$ & W & 1 & 102.2 & 2 \\
\hline acanthochory & $\mathrm{Te}$ & W & 2 & 1 & 1 \\
\hline barochory & $\mathrm{Te}$ & W & 1 & 62 & 1 \\
\hline pterochory & $\mathrm{Fa}$ & $\mathrm{N}$ & 1 & 2.58 & 3 \\
\hline sporochory & $\mathrm{Cr}$ & $\mathrm{N}$ & 48.82 & 1 & 3 \\
\hline sclerochory & $\mathrm{Te}$ & EW & 1 & 81.33 & 1 \\
\hline sporochory & $\mathrm{Te}$ & W & 0 & 8 & 1 \\
\hline pterochory & $\mathrm{Fa}$ & $\mathrm{N}$ & 1 & 3.07 & 6 \\
\hline sarcochory & $\mathrm{Fa}$ & $\mathrm{N}$ & 1 & 9 & 1 \\
\hline sarcochory & $\mathrm{Fa}$ & $\mathrm{N}$ & 10 & 0 & 1 \\
\hline sporochory & $\mathrm{Te}$ & $\mathrm{N}$ & 1 & 29.22 & 3 \\
\hline pterochory & $\mathrm{Fa}$ & EW & 2 & 0 & 1 \\
\hline barochory & $\mathrm{He}$ & EW & 0 & 2 & 1 \\
\hline sporochory & $\mathrm{Ca}$ & $\mathrm{N}$ & 351.33 & 1 & 3 \\
\hline sporochory & $\mathrm{Fa}$ & $\mathrm{N}$ & 2551 & 0 & 3 \\
\hline pterochory & $\mathrm{Cr}$ & $\mathrm{N}$ & 0 & 106 & 1 \\
\hline sporochory & $\mathrm{Te}$ & W & 1 & 39 & 1 \\
\hline sporochory & $\mathrm{Ca}$ & $\mathrm{N}$ & 1 & 1 & 1 \\
\hline sclerochory & $\mathrm{Te}$ & W & 1 & 1.75 & 1 \\
\hline sporochory & $\mathrm{Te}$ & W & 0 & 1 & 1 \\
\hline barochory & $\mathrm{Ca}$ & W & 3 & 0 & 1 \\
\hline sclerochory & $\mathrm{Fa}$ & $\mathrm{N}$ & 2.87 & 1 & 1 \\
\hline pterochory & $\mathrm{Fa}$ & $\mathrm{N}$ & 2.12 & 1 & 3 \\
\hline barochory & $\mathrm{He}$ & $\mathrm{N}$ & 0 & 3 & 1 \\
\hline barochory & $\mathrm{He}$ & $\mathrm{N}$ & 0 & 4 & 1 \\
\hline
\end{tabular}


Appendix 1. Continues.

Class/Family/Species

\section{Hydrophyllaceae}

Wigandia urens (Ruiz et Pav.) Kunth

Lamiaceae

Leonotis nepetifolia (L.) R. Brown

Salvia mexicana Sessé et Moc.

Salvia tiliifolia Vahl

Lythraceae

Cuphea wrightii A. Gray

Myrtaceae

Eucalyptus resinifera Smith

Oleaceae

Fraxinus uhdei (Wenz.) Lingelsh

Oxalidaceae

Oxalis lunulata Zucc.

Passifloraceae

Passiflora subpeltata Ortega

Phytolaccaceae

Phytolacca icosandra L.

Polygonaceae

Rumex obtusifolius L.

\section{Portulacaceae}

Portulaca mexicana P. Wilson

Rubiaceae

Bouvardia ternifolia (Cav.) Schltdl.

Crusea longiflora (Wild. Ex Roem. et Schult.) W.R.

Anderson

Galium uncinulatum DC.

\section{Sapindaceae}

Cardiospermum halicacabum L.

Dodonaea viscosa Jacq.

\section{Scrophulariaceae}

Penstemon campanulatus (Cav.) Willd.

Solanaceae

Jaltomata procumbens (Cav.) J.L. Gentry

Nicotiana glauca Graham

Physalis patula Mill.

Vitaceae

Cissus sicyoides L.

\section{Liliopsida}

\section{Agavaceae}

Agave salmiana Otto ex Salm-Dyck

Manfreda scabra (Ort.) McVaugh

\begin{tabular}{|c|c|c|c|c|c|}
\hline $\begin{array}{l}\text { Dispersal } \\
\text { syndrome }\end{array}$ & $\begin{array}{l}\text { Life } \\
\text { form }\end{array}$ & $\begin{array}{l}\text { Type of } \\
\text { species }\end{array}$ & $\begin{array}{c}\text { Relation in } \\
\text { unburned } \\
\text { site }\end{array}$ & $\begin{array}{c}\text { Relation } \\
\text { in burned } \\
\text { site }\end{array}$ & $\begin{array}{c}\text { Abundance } \\
\text { category }\end{array}$ \\
\hline sporochory & $\mathrm{Fa}$ & $\mathrm{W}$ & 1 & 60.16 & 5 \\
\hline barochory & $\mathrm{Te}$ & EW & 0 & 1 & 1 \\
\hline sclerochory & $\mathrm{He}$ & W & 4 & 1 & 1 \\
\hline sclerochory & $\mathrm{He}$ & W & 1 & 2 & 1 \\
\hline ascochory & $\mathrm{Te}$ & $\mathrm{W}$ & 5 & 0 & 1 \\
\hline sporochory & $\mathrm{Fa}$ & $\mathrm{E}$ & 7.81 & 1 & 1 \\
\hline pterochory & $\mathrm{Fa}$ & $\mathrm{N}$ & 3 & 0 & 1 \\
\hline sporochory & $\mathrm{Cr}$ & $\mathrm{N}$ & 1 & 2 & 1 \\
\hline sarcochory & $\mathrm{He}$ & W & 149 & 0 & 1 \\
\hline sarcochory & $\mathrm{Ca}$ & W & 1 & 14 & 1 \\
\hline sporochory & $\mathrm{He}$ & EW & 16 & 0 & 1 \\
\hline sporochory & $\mathrm{He}$ & $\mathrm{N}$ & 0 & 1 & 1 \\
\hline pterochory & $\mathrm{Fa}$ & W & 1.79 & 1 & 1 \\
\hline sclerochory & $\mathrm{Te}$ & W & 17 & 1 & 1 \\
\hline acanthochory & $\mathrm{He}$ & $\mathrm{N}$ & 1 & 5 & 1 \\
\hline barochory & $\mathrm{He}$ & W & 2 & 0 & 1 \\
\hline pterochory & $\mathrm{Fa}$ & W & 3.54 & 1 & 1 \\
\hline sclerochory & $\mathrm{Ca}$ & $\mathrm{N}$ & 0 & 22 & 1 \\
\hline sarcochory & $\mathrm{Te}$ & W & 0 & 54 & 1 \\
\hline sporochory & $\mathrm{Fa}$ & EW & 1 & 7 & 1 \\
\hline sarcochory & $\mathrm{He}$ & W & 0 & 272 & 1 \\
\hline sarcochory & $\mathrm{Ca}$ & $\mathrm{N}$ & 5.75 & 1 & 1 \\
\hline
\end{tabular}


Appendix 1. Continues.

Class/Family/Species

\section{Alliaceae}

Milla biflora Cav.

Bromeliaceae

Tillandsia recurvata (L.) L.

Calochortaceae

Calochortus barbatus (Kunth) Painter

\section{Commelinaceae}

Commelina diffusa Burm. f.

Commelina tuberosa L.

\section{Cyperaceae}

Bulbostylis juncoides (Vahl) Kük. ex Osten

Cyperus esculentus L.

Cyperus manimae Kunth.

\section{Hipoxidaceae}

Hypoxis mexicana Schult. et Schult. F.

\section{Poaceae}

Aegopogon tenellus (DC.) Trin

Chloris gayana Kunth.

Chloris virgata $\mathrm{Sw}$.

Digitaria ternata (A.Rich.) Staff

Microchloa kunthii Desv.

Muhlenbergia rigida (Kunth)

Muhlenbergia robusta (E. Fourn.) Hitchc

Paspalum postratum Scribn. Et Meer.

Paspalum tenellum Willd.

Rhynchelytrum repens (Willd.) C.E. Hubb.

Setaria grisebachii E. Fourn.

Setaria parviflora (Poir.) Kerguélen.

Sporobolus atrovirens (Kunth) Kunth

Tripsacum dactyloides (L.) L.

$\begin{array}{cccccc}\text { Dispersal } & \text { Life } & \text { Type of } & \text { Relation in } & \text { Relation } & \text { Abundance } \\ \text { syndrome } & \text { form } & \text { species } & \begin{array}{c}\text { unburned } \\ \text { site }\end{array} & \begin{array}{c}\text { in burned } \\ \text { site }\end{array} & \text { category }\end{array}$

\begin{tabular}{|c|c|c|c|c|c|}
\hline sclerochory & $\mathrm{Cr}$ & W & 1 & 6 & 1 \\
\hline pogonochory & $\mathrm{Fa}$ & $\mathrm{N}$ & 1 & 3.29 & 1 \\
\hline sclerochory & $\mathrm{Cr}$ & W & 1 & 67 & 1 \\
\hline sclerochory & $\mathrm{He}$ & W & 0 & 1 & 1 \\
\hline sclerochory & $\mathrm{He}$ & $\mathrm{N}$ & & 2 & 1 \\
\hline sporochory & $\mathrm{Cr}$ & $\mathrm{N}$ & 2.4 & 1 & 1 \\
\hline sporochory & $\mathrm{Cr}$ & EW & 1 & 34 & 3 \\
\hline sclerochory & $\mathrm{Cr}$ & W & 27.09 & 1 & 2 \\
\hline sclerochory & $\mathrm{Cr}$ & $\mathrm{W}$ & 1 & 2.38 & 1 \\
\hline sclerochory & $\mathrm{Te}$ & W & 4.73 & 1 & 1 \\
\hline sclerochory & $\mathrm{He}$ & EW & 2 & 1 & 1 \\
\hline pogonochory & $\mathrm{Te}$ & W & 1 & 5.17 & 1 \\
\hline sclerochory & $\mathrm{Te}$ & EW & 84 & 1 & 1 \\
\hline sclerochory & $\mathrm{He}$ & $\mathrm{N}$ & 17 & 0 & 1 \\
\hline sclerochory & $\mathrm{He}$ & $\mathrm{N}$ & 1 & 9.5 & 1 \\
\hline sclerochory & $\mathrm{Ca}$ & $\mathrm{N}$ & 1 & 2.75 & 6 \\
\hline sacochory & $\mathrm{Te}$ & W & 2.23 & 1 & 1 \\
\hline sacochory & $\mathrm{He}$ & W & 0 & 71 & 1 \\
\hline pogonochory & $\mathrm{He}$ & EW & 1 & 9.13 & 3 \\
\hline sacochory & $\mathrm{Te}$ & W & 1 & 18.71 & 1 \\
\hline sacochory & $\mathrm{Te}$ & W & 1 & 7.29 & 1 \\
\hline sacochory & $\mathrm{He}$ & $\mathrm{N}$ & 60 & 1 & 1 \\
\hline sclerochory & $\mathrm{Fa}$ & $\mathrm{N}$ & 0 & 13 & 1 \\
\hline
\end{tabular}

